\title{
Aortic Preductal Coarctation Severity
}

National Cancer Institute

\section{Source}

National Cancer Institute. Aortic Preductal Coarctation Severity. NCI Thesaurus. Code C139034.

The assessment of the severity of preductal aortic coarctation. 